\title{
Food habits in pregnancy and its association with gestational diabetes mellitus: results from a prospective cohort study in public hospitals of urban India
}

\author{
R. Deepa', Melissa Glenda Lewis ${ }^{2}$, Onno C. P. Van Schayck ${ }^{3}$ and Giridhara R. Babu ${ }^{4,5^{*}}$
}

\begin{abstract}
Background: Few studies have explored the relationship between food habits and the risk of gestational diabetes mellitus (GDM) in women from India. We aimed to investigate the associations of food habits and the risk of GDM.

Methods: As part of the MAASTHI prospective cohort study in urban Bengaluru, India, pregnant women between 18 and 45 years, less than 36 weeks of gestation were included. During baseline, the participant's age, education, physical activity levels, and food habits were recorded. Screening of GDM was done by the World Health Organization diagnostic criteria using a 2-h 75-g oral glucose tolerance test between the 24th-36th weeks of gestation.

Results: We included 1777 pregnant women in the study. We show that 17.6\% of the women had GDM, of which $76.7 \%$ consume red meat. Red meat consumption was associated with an increased risk of GDM (aRR $=2.1,95 \% \mathrm{Cl} 1.5$, 2.9) after adjusting for age, family history of diabetes and socioeconomic status.

Conclusion: The high intake of red meat consumption in pregnancy needs further examination. Also, future evaluations should consider evaluating the risk of red meat consumption against the combined effect of inadequate consumption of vegetables, fruits, and dairy products in pregnant women. Interventions to educate women in lower socioeconomic status on inexpensive, seasonal, and healthy food might be helpful.
\end{abstract}

Keywords: Gestational diabetes, Diet, Red meat, Pregnancy, India

\section{Background}

Gestational diabetes mellitus (GDM) is carbohydrate intolerance resulting in hyperglycemia of variable severity with onset or first recognition during pregnancy [1]. GDM can lead to several adverse outcomes in the infant. These include fetal hyperglycemia, macrosomia, shoulder dystocia, respiratory distress syndrome, fetal hypoglycemia,

\footnotetext{
* Correspondence: epigiridhar@gmail.com

${ }^{4}$ Lifecourse epidemiology, Indian Institute of Public Health-Bangalore, Public Health Foundation of India (PHFI), Magadi Road I cross, SIHFW premises, Bengaluru 560023, India

${ }^{5}$ Public health and clinical medicine, Wellcome Trust/DBT India Alliance, New Delhi, India

Full list of author information is available at the end of the article
}

prematurity, hypocalcaemia, and hyperbilirubinemia [2-6]. Additionally, children borne of women with GDM are more likely to develop obesity and type 2 diabetes mellitus (T2DM) [7, 8]. Also, the mother is at risk for preeclampsia, caesarean sections, and increased risk in the future for T2DM. Globally, GDM affects 18.4 million women, which accounts for $86.4 \%$ of gestational hyperglycemia, defined as any higher levels of glucose [9]. In South Asia alone, the prevalence of GDM is increasing with current estimates indicating $26.6 \%$ [9] and in urban India vary in different regions, from 0.56 to $41.9 \%$ [10, 11]. Therefore, early detection and treatment of GDM must be implemented to

(c) The Author(s). 2020 Open Access This article is licensed under a Creative Commons Attribution 4.0 International License, which permits use, sharing, adaptation, distribution and reproduction in any medium or format, as long as you give appropriate credit to the original author(s) and the source, provide a link to the Creative Commons licence, and indicate if changes were made. The images or other third party material in this article are included in the article's Creative Commons licence, unless indicated otherwise in a credit line to the material. If material is not included in the article's Creative Commons licence and your intended use is not permitted by statutory regulation or exceeds the permitted use, you will need to obtain permission directly from the copyright holder. To view a copy of this licence, visit http://creativecommons.org/licenses/by/4.0/ The Creative Commons Public Domain Dedication waiver (http://creativecommons.org/publicdomain/zero/1.0/) applies to the data made available in this article, unless otherwise stated in a credit line to the data. 
improve outcomes for both mother and child in these women [12, 13].

Advanced maternal age, high body mass index (BMI), a family history of T2DM are significant independent risk factors for hyperglycemia in pregnancy [14]. Among other modifiable risk factors of GDM, tackling obesity is essential; even moderate changes in pre-pregnancy weight have shown to affect the risk of gestational diabetes among obese women [5, 15-17]. Studies have also shown that minor degrees of carbohydrate intolerance are related to obesity [18]. Furthermore, Indians are known to have the thin-fat phenotype that is characterized by an excessive accumulation of fat for lower BMI [19]. Several studies have proven that adults who had a low birth weight are more likely to develop higher glucose concentration and insulin resistance and adiposity [20]. Low birth weight and subsequent risk of non-communicable diseases have been associated with maternal diets that are poor in micronutrients [21]. Therefore lifestyle factors such as lack of exercise and diet composition are modifiable predictors of risk for abnormal glucose tolerance during pregnancy. Hence apart from screening and managing GDM, it is essential to identify and control the factors leading to glucose intolerance in pregnancy. In the Indian context, identifying nutritional risk factors will enable us to screen and prevent GDM in this setting.

The available evidence regarding the relation of GDM with nutritional factors is not clear. Some studies have suggested that diets high in total fat, saturated fat, and lower consumption of carbohydrate, fruits, and vegetables during pregnancy are associated with a higher risk of developing GDM [22-25]. The SUN cohort in Spain demonstrates high consumption of potato, fast food, and sugarsweetened beverages before pregnancy are independently associated with GDM [26, 27]. Studies that have examined food groups and dietary patterns found that GDM was predicted by high intake of red and processed meats and a Western-type dietary pattern (i.e., high in red meat, refined sugars, and fried or snack foods) [28, 29].

Few studies have explored the relationship between dietary patterns and the risk of GDM of women from India, especially from the lower socioeconomic settings. There is limited knowledge regarding dietary habits as well as its association with GDM in pregnant Indian women attending public hospitals. As a result, there is a coexistence of malnutrition in the mother and the fetus associated with these conditions [30]. Understanding the nutritional risk factors and its association with GDM can inform the policies in improving the health of women attending public hospitals. We aimed to investigate associations of food habits in pregnant women with the risk of GDM in the urban Indian women of the lower socioeconomic strata. We hypothesize that low intake of vegetables and high animal origin food among pregnant women of lower socioeconomic strata are associated with the risk of GDM.

\section{Methods \\ Study design and setting}

Maternal Antecedents of Adiposity and Studying the Transgenerational role of Hyperglycemia and Insulin (MAASTHI) is an ongoing prospective cohort study. The cohort recruited pregnant women from public hospitals in Bengaluru, India. The primary objective of the MAASTHI Cohort is to study the association between maternal hyperglycemia and the risk of non-communicable diseases in infants. The participating hospital had an obstetric department that caters to the urban population of Bengaluru in the surrounding vicinity. A detailed protocol and related publications can be found elsewhere [17, 31].

In brief, we screened all pregnant women attending antenatal clinics in public hospital and obtained consent from eligible women to participate voluntarily in the cohort. The participants were enrolled from April 2016 to September 2018. Women entered the study if a singleton pregnancy of 14-weeks' gestation was confirmed. All pregnant women between the age of 18-45 years less than 36 weeks of gestation and willing to provide informed consent were included. We excluded women with coexisting severe illness. Ultrasonography reports were used to estimate the gestational age, and in the absence of ultrasonography reports, the participant's last menstrual period was recorded.

\section{Food habit assessment}

The food habits of the participants were recorded at the baseline using an interviewer-administered food propensity questionnaire to elicit the frequency of food consumption in the last month. Based on the cultural and local context, we prepared a list of foods more frequently consumed in this population. Food groups like vegetables, fruits, eggs, dairy, red meat, chicken, fish, nuts, cereal, cooking oil, fried food, and other habits like eating out were recorded. The participants were asked to indicate how often they consumed the particular food item. The questionnaire had five options for frequency of consumption ranging from "Never" to "daily." (Additional file 1). The questionnaire was administered before undergoing the oral glucose tolerance test.

\section{Assessment of non-dietary covariates}

After the baseline interview, our trained research staff recorded the anthropometric measurements in a separate room, assuring privacy to the pregnant women. Using a digital weighing scale (Tanita) weight to the nearest $0.1 \mathrm{~kg}$ and using portable stadiometer (SECA 213) height of the mother to the nearest $0.1 \mathrm{~cm}$ were measured. The skinfold thickness at biceps, triceps and subscapular sites were 
Table 1 Distribution of demographic characteristics among pregnant women with GDM and without GDM (N=1777)

\begin{tabular}{|c|c|c|c|c|c|}
\hline \multirow[t]{2}{*}{ Characteristics of the cohort } & \multirow[t]{2}{*}{ Categories } & \multicolumn{2}{|l|}{ GDM status } & \multirow{2}{*}{$\begin{array}{l}\text { Total } \\
\text { N (\%) }\end{array}$} & \multirow[t]{2}{*}{$P$-value } \\
\hline & & Yes $(n=313)$ & No $(n=1464)$ & & \\
\hline Age (years) & Mean $\pm S D$ & $25.9 \pm 4.4$ & $24.0 \pm 4.0$ & $24.3 \pm 4.1$ & $<0.001^{*}$ \\
\hline Gestational age at baseline (weeks) & Mean \pm SD & $23.9 \pm 5.4$ & $23.8 \pm 5.4$ & $23.8 \pm 5.3$ & 0.95 \\
\hline Gestational age at the time of OGTT weeks) & Mean $\pm S D$ & $28.1 \pm 2.6$ & $28.1 \pm 2.9$ & $28.1 \pm 2.9$ & 0.90 \\
\hline \multirow[t]{3}{*}{ Religion } & Hinduism & $142(45.4)$ & $677(46.2)$ & $819(46.0)$ & 0.95 \\
\hline & Christianity & 12(3.6) & $53(3.7)$ & $65(3.7)$ & \\
\hline & Islam & 159(50.8) & 734(50.1) & $893(50.3)$ & \\
\hline \multirow[t]{6}{*}{ Participant Education } & Illiterate & $12(3.8)$ & $43(2.9)$ & $55(3.1)$ & 0.06 \\
\hline & Primary School & $21(6.7)$ & $78(5.3)$ & $99(5.6)$ & \\
\hline & Middle School & 43(13.7) & $267(18.2)$ & $310(17.4)$ & \\
\hline & High School & 134(42.8) & $641(43.8)$ & $775(43.6)$ & \\
\hline & PUC or Diploma ${ }^{a}$ & $64(20.4)$ & $309(21.1)$ & $373(21.0)$ & \\
\hline & Graduate and above & $39(12.5)$ & 126(8.6) & $165(9.2)$ & \\
\hline \multirow[t]{7}{*}{ Husband's Education } & Illiterate & 28(8.9) & 139(9.5) & $167(9.4)$ & 0.41 \\
\hline & Primary School & $27(8.6)$ & $150(10.2)$ & $177(10.0)$ & \\
\hline & Middle School & $57(18.2)$ & $281(19.2)$ & $338(19.0)$ & \\
\hline & High School & 124(39.6) & $559(38.2)$ & $683(38.4)$ & \\
\hline & PUC or Diploma ${ }^{a}$ & 59(18.8) & 214(14.6) & 273(15.4) & \\
\hline & Graduate and above & $18(5.8)$ & 115(7.9) & 133(7.5) & \\
\hline & Do not know & $0(0.0)$ & $6(0.4)$ & $6(0.3)$ & \\
\hline \multirow[t]{3}{*}{ Participant's Occupation ${ }^{b}$} & Unemployed & 283(90.4) & $1361(93.0)$ & $1644(92.5)$ & 0.10 \\
\hline & Unskilled & $15(4.8)$ & $70(4.8)$ & $85(4.8)$ & \\
\hline & Semi-skilled/ Skilled & $15(4.8)$ & $33(2.3)$ & $48(2.7)$ & \\
\hline \multirow[t]{5}{*}{ Husband's Occupation ${ }^{\text {b }}$} & Unemployed & $1(0.3)$ & $4(0.3)$ & $5(0.3)$ & 0.30 \\
\hline & Unskilled & $155(49.5)$ & $776(53.0)$ & $931(52.4)$ & \\
\hline & Semi-skilled & $88(28.1)$ & $405(27.7)$ & $488(27.5)$ & \\
\hline & Skilled & $60(19.2)$ & $223(15.2)$ & 283(15.9) & \\
\hline & Clerical or Professional & $14(4.5)$ & $56(3.8)$ & $70(4.0)$ & \\
\hline \multirow[t]{2}{*}{ Socioeconomic class } & Lower & $177(56.5)$ & $937(64.0)$ & $1114(62.7)$ & $0.01^{*}$ \\
\hline & Middle & $136(43.5)$ & $527(36.0)$ & $663(37.3)$ & \\
\hline \multirow[t]{3}{*}{ Gravida } & One & 105(33.5) & $588(40.2)$ & 693(39.0) & 0.10 \\
\hline & Two & 129(41.2) & $546(37.3)$ & 675(38.0) & \\
\hline & Three or more & $79(25.2)$ & $330(22.5)$ & $409(23.0)$ & \\
\hline \multirow[t]{3}{*}{ Parity } & Nulliparous & $133(42.5)$ & $666(45.5)$ & $799(45.0)$ & 0.62 \\
\hline & Primiparous & 143(45.7) & $637(43.5)$ & $780(43.9)$ & \\
\hline & Multiparous & $37(11.8)$ & $161(11.0)$ & 198(11.1) & \\
\hline \multirow[t]{3}{*}{ History of Abortion } & No history & $230(73.5)$ & 1154(78.8) & 1384(77.9) & 0.07 \\
\hline & Once & $68(21.7)$ & $252(17.2)$ & $320(18.0)$ & \\
\hline & $\geq$ twice & $15(4.8)$ & $58(4.0)$ & $73(4.1)$ & \\
\hline \multirow[t]{2}{*}{ Anemia } & Present & 127(40.6) & $645(44.1)$ & $772(43.5)$ & 0.24 \\
\hline & Absent & 186(59.4) & $815(55.7)$ & $1001(56.3)$ & \\
\hline \multirow[t]{3}{*}{ Family history of Diabetes Mellitus } & Absent & 197(62.9) & 1134(77.5) & $1331(75.0)$ & $<0.001^{*}$ \\
\hline & One parent & $92(29.4)$ & $286(19.5)$ & $378(21.3)$ & \\
\hline & Two parents & $24(7.7)$ & $40(2.7)$ & 64(3.6) & \\
\hline
\end{tabular}


Table 1 Distribution of demographic characteristics among pregnant women with GDM and without GDM (N=1777) (Continued)

\begin{tabular}{|c|c|c|c|c|c|}
\hline \multirow[t]{2}{*}{ Characteristics of the cohort } & \multirow[t]{2}{*}{ Categories } & \multicolumn{2}{|l|}{ GDM status } & \multirow{2}{*}{$\begin{array}{l}\text { Total } \\
\text { N (\%) }\end{array}$} & \multirow[t]{2}{*}{$P$-value } \\
\hline & & Yes $(n=313)$ & No $(n=1464)$ & & \\
\hline \multirow[t]{2}{*}{ Metabolic Equivalent of Task (MET) } & Low & $8(2.6)$ & $35(2.4)$ & $43(2.4)$ & 0.8 \\
\hline & Moderate & $305(97.4)$ & 1429(97.6) & 1734(97.6) & \\
\hline Sum of skin fold thickness (mm) & Mean \pm SD & $18.4 \pm 4.7$ & $15.3 \pm 4.6$ & $15.9 \pm 4.8$ & $<0.001^{*}$ \\
\hline Body mass index (BMI) & Mean \pm SD & $27.3 \pm 5.2$ & $24.4 \pm 4.3$ & $24.9 \pm 4.6$ & $<0.001^{*}$ \\
\hline
\end{tabular}

* Statistically significant at $5 \%$ level of significance

${ }^{a}$ PUC Pre-university certification

bUnskilled: laborer, construction laborer, helper, attender; peon, cleaner, sweeper

Semi-Skilled: Gatekeeper/Security, Asst. Operator, Asst. electrician, waiter

Skilled: Tailor, carpenter, driver, plumber, electrician

measured using a Holtain skinfold caliper; (Holtain $610 \mathrm{ND}$ ) and the average of three readings was taken. Sum of skinfold was calculated by adding bicep, triceps and subscapular skinfolds. We assessed the physical activity levels of the pregnant woman using a validated questionnaire [32] that captures the activities performed in a week, the duration of each activity, and frequencies of the activities were noted. We estimated the Metabolic Equivalent of Task (MET) values of each activity by multiplying MET allotted value, duration of the activity, and frequency performed in a week. The level of physical activity was defined as low if it was $<600$ METs, moderate when 6002999 METs, and as high when it is ( $\geq 3000$ METs. The socioeconomic status was categorized based on the Kuppuswamy scale using education, occupation, and income, into upper, upper- middle, lower-middle, upper-lower, and lower. For analysis, purpose only two main categories of lower (upper-lower, and lower) and middle (upper middle, lower middle) was created [33].

\section{Ascertainment of GDM}

A 2-h 75-g oral glucose tolerance test was performed during the 24th-36th week of gestation. Diagnostic cutoff points, as defined by the International Association of the Diabetes and Pregnancy Study Groups (IADPSG), for fasting $\geq 92 \mathrm{mg} / \mathrm{dL}$ and 2-h (postprandial) $\geq 153 \mathrm{mg} /$ $\mathrm{dL}$. One glucose value equal to or above any cut-off point was considered for the diagnosis of GDM [34]. Pregnant women's hemoglobin values were also tested, and values less than $11 \mathrm{~g} / \mathrm{dL}$ was considered as anemia.

\section{Statistical analyses}

Descriptive statistics were performed using IBM SPSS Software Version 23 [35]. It was done for maternal characteristics and food habits for women with and without GDM. Categorical variables were expressed as frequency and percentages (\%) and normally distributed variables as mean and standard deviation. Missing data were analyzed using available case analysis. Association between food habits with GDM status was assessed using the Chisquare test to determine the food variables for multivariable regression models. Modified Poisson regression with robust variance analysis was performed in $\mathrm{R}$ Version 3.6.2 [36] to determine the association between food habits with GDM. This was adjusted for maternal age, family history of diabetes, socioeconomic class, body mass index (BMI), the sum of skinfold thickness, metabolic equivalent of task (MET) and gestational age. Confounders were selected based on the parameters that were significant in univariate analysis. Adjusted relative risk (aRR), unadjusted relative risk (RR), 95\% confidence intervals $(\mathrm{CI})$ along with $p$-values have been reported, where $p$ values $\leq 0.05$ is considered statistically significant.

\section{Results}

A total of 1777 pregnant women from the ongoing MAAS THI cohort were selected for this study. The mean age was 24.3 years, $50.3 \%$ were Muslim, $96.9 \%$ attended school, and most of them were unemployed (92.5\%). A majority $(62.7 \%)$ belonged to lower socioeconomic status. Of the total, $45.0 \%$ of the women were nulliparous, $43.5 \%$ anemic, $22.1 \%$ had a history of abortion, and $17.6 \%(n=313)$ were diagnosed with GDM in the current pregnancy.

The mean age of women with GDM $(25.9 \pm 4.4$ years $)$ was higher compared to women without GDM (24.0 \pm 4.0 years) and was statistically significant. We found that socioeconomic status of women and having a family history of diabetes mellitus was statistically significant with GDM. Women with GDM had a higher sum of skinfold thickness (18.4 \pm 4.7$)$ compared to normoglycemic women $(15.3 \pm 4.6)$. Women diagnosed with GDM also had higher BMI $(27.3 \pm 5.2)$ when compared to women without GDM $(24.4 \pm 4.3)$. (Table 1$)$.

\section{Food habit and its association with GDM}

Among women with GDM, 76.7\% consume red meat, $66.3 \%$ consume fried food, $42.9 \%$ eat out, $98.8 \%$ eat fruits, $97.8 \%$ consume vegetables, $90.8 \%$ consume polished rice, only $8.0 \%$ use palm oil for cooking, $28.7 \%$ drink coffee, $50.0 \%$ drink tea, $83.4 \%$ consume dairy products, $76.1 \%$ consume eggs, $82.2 \%$ consume chicken, and $66.2 \%$ consume fish. However, there was no statistically 
Table 2 Univariate analysis of dietary habits with GDM status of pregnant women $(N=1777)$

\begin{tabular}{|c|c|c|c|c|c|}
\hline \multirow[t]{2}{*}{ Dietary habit } & \multirow[t]{2}{*}{ Categories } & \multicolumn{2}{|l|}{ GDM status } & \multirow{2}{*}{$\begin{array}{l}\text { Total } \\
\mathrm{n}(\%)\end{array}$} & \multirow{2}{*}{$\begin{array}{l}P \text { - } \\
\text { value }\end{array}$} \\
\hline & & Yes $(n=313)$ & No $(n=1464)$ & & \\
\hline \multirow[t]{6}{*}{ Red meat consumption } & Never & $73(23.2)$ & $420(28.7)$ & $493(27.7)$ & $0.02^{*}$ \\
\hline & $<1$ per month & $13(4.1)$ & $27(1.8)$ & $40(2.3)$ & \\
\hline & 1-3 times /month & $53(17.2)$ & 190(12.9) & $243(13.7)$ & \\
\hline & 1-3 times/week & 153(48.7) & $745(50.8)$ & $898(50.5)$ & \\
\hline & $>3$ times / week & $10(3.2)$ & $36(2.4)$ & $46(2.6)$ & \\
\hline & Daily & $11(3.5)$ & $46(3.1)$ & $57(3.2)$ & \\
\hline \multirow[t]{5}{*}{ Fried food } & Never & 105(33.8) & $470(32.1)$ & $575(32.4)$ & 0.96 \\
\hline & $<1$ per week & $93(29.6)$ & $448(30.6)$ & $541(30.4)$ & \\
\hline & 1-3 times a week & 101(32.2) & $470(32.1)$ & $571(32.1)$ & \\
\hline & 4 to 6 times a week & $5(1.6)$ & $25(1.7)$ & $30(1.7)$ & \\
\hline & Daily & $9(2.9)$ & $51(3.4)$ & $60(3.4)$ & \\
\hline \multirow[t]{5}{*}{ Eating out } & Never & 178(57.0) & $821(56.0)$ & $999(56.2)$ & 0.96 \\
\hline & $<1$ per week & $87(27.7)$ & $428(29.2)$ & $515(29.0)$ & \\
\hline & 1-3 times a week & $46(14.6)$ & $205(14.0)$ & $251(14.1)$ & \\
\hline & 4 to 6 times a week & $1(0.3)$ & $7(0.4)$ & $8(0.5)$ & \\
\hline & Daily & $1(0.3)$ & $3(0.2)$ & $4(0.2)$ & \\
\hline \multirow[t]{5}{*}{ Fruits } & Never & $5(1.6)$ & $38(2.5)$ & $43(2.4)$ & 0.22 \\
\hline & $<1$ serving /day & $112(35.7)$ & $476(32.5)$ & $588(33.1)$ & \\
\hline & 2-4 servings / day & $167(53.5)$ & $757(51.7)$ & $924(52.0)$ & \\
\hline & 5-6 servings / day & $16(5.1)$ & $92(6.2)$ & $108(6.1)$ & \\
\hline & $>6$ servings / day & $13(4.1)$ & $101(6.8)$ & $114(6.4)$ & \\
\hline \multirow[t]{5}{*}{ Vegetables } & Never & $7(2.2)$ & $33(2.2)$ & $40(2.3)$ & 0.30 \\
\hline & $<1$ serving /day & $90(28.7)$ & $444(30.3)$ & $534(30.1)$ & \\
\hline & 2-4 servings / day & 186(59.6) & $794(54.2)$ & $980(55.1)$ & \\
\hline & 5-6 servings /day & $17(5.4)$ & $93(6.3)$ & $110(6.2)$ & \\
\hline & $>6$ serving /day & $13(4.1)$ & $100(6.8)$ & $113(6.4)$ & \\
\hline \multirow[t]{2}{*}{ Polished Rice } & No & $29(9.2)$ & 109(7.4) & 138(7.8) & 0.28 \\
\hline & Yes & 284(90.8) & 1355(92.5) & 1639(92.2) & \\
\hline \multirow[t]{3}{*}{ Palm oil for cooking } & Sunflower & $267(85.3 \%)$ & 1186(81\%) & $1453(81.8 \%)$ & 0.08 \\
\hline & Palm & $25(8 \%)$ & $183(12.5 \%)$ & $208(11.7 \%)$ & \\
\hline & Others $^{a}$ & $21(6.7 \%)$ & $95(6.5 \%)$ & $116(6.5 \%)$ & \\
\hline \multirow[t]{3}{*}{ Coffee } & Never & $224(71.3)$ & $997(68.1)$ & $1221(68.7)$ & 0.47 \\
\hline & $1-2$ cups a day & $86(27.70)$ & 453(30.9) & $539(30.3)$ & \\
\hline & $>2$ cups a day & $3(1.0)$ & $14(1.0)$ & $17(1.0)$ & \\
\hline \multirow[t]{3}{*}{ Tea } & Never & $156(50.0)$ & $760(51.9)$ & $916(51.5)$ & 0.80 \\
\hline & $1-2$ cups a day & $145(46.2)$ & $651(44.4)$ & $796(44.8)$ & \\
\hline & $>2$ cups a day & $12(3.8)$ & $53(3.6)$ & $65(3.7)$ & \\
\hline \multirow[t]{6}{*}{ Dairy } & Never & $51(16.6)$ & 283(19.3) & $334(18.8)$ & 0.51 \\
\hline & $<1$ per month & $5(1.6)$ & $18(1.2)$ & $23(1.3)$ & \\
\hline & 1-3 times /month & $0(0)$ & $4(0)$ & $4(0.2)$ & \\
\hline & 1-3 times/week & $48(15.3)$ & $181(12)$ & $229(12.9)$ & \\
\hline & $>3$ times / week & $2(0.6)$ & $12(1)$ & $14(0.8)$ & \\
\hline & Daily & $207(65.9)$ & $966(66)$ & $1173(66.0)$ & \\
\hline
\end{tabular}


Table 2 Univariate analysis of dietary habits with GDM status of pregnant women ( $N=1777)$ (Continued)

\begin{tabular}{|c|c|c|c|c|c|}
\hline \multirow[t]{2}{*}{ Dietary habit } & \multirow[t]{2}{*}{ Categories } & \multicolumn{2}{|l|}{ GDM status } & \multirow{2}{*}{$\begin{array}{l}\text { Total } \\
\mathrm{n}(\%)\end{array}$} & \multirow{2}{*}{$\begin{array}{l}P \text { - } \\
\text { value }\end{array}$} \\
\hline & & Yes $(n=313)$ & No $(n=1464)$ & & \\
\hline \multirow[t]{6}{*}{ Eggs } & Never & 74(23.9) & $340(23)$ & $414(23.3)$ & 0.63 \\
\hline & $<1$ per month & $7(2.2)$ & $34(2)$ & $41(2.3)$ & \\
\hline & 1-3 times /month & $16(5.1)$ & $61(4)$ & $77(4.3)$ & \\
\hline & 1-3 times/week & 163(51.9) & $816(56)$ & $979(55.1)$ & \\
\hline & $>3$ times / week & $17(5.4)$ & $53(4)$ & 70(3.9) & \\
\hline & Daily & $36(11.5)$ & $160(11)$ & 196(11.0) & \\
\hline \multirow[t]{5}{*}{ Chicken } & Never & $56(17.8)$ & $282(19)$ & 338(19.0) & 0.89 \\
\hline & $<1$ per month & $6(1.9)$ & $36(3)$ & $42(2.4)$ & \\
\hline & 1-3 times /month & $35(11.5)$ & $142(10)$ & $177(10.0)$ & \\
\hline & 1-3 times/week & 198(63.1) & $934(64)$ & $1132(63.7)$ & \\
\hline & $>3$ times / week & $18(5.7)$ & $70(5)$ & $88(5.0)$ & \\
\hline \multirow[t]{4}{*}{ Fish } & Never & 105(33.8) & $570(39)$ & $675(38.0)$ & 0.34 \\
\hline & $<1$ per month & 25(8.0) & $94(6)$ & $119(6.7)$ & \\
\hline & 1-3 times /month & $80(25.5)$ & $383(26)$ & $463(26.1)$ & \\
\hline & 1-3 times/week & 103(32.8) & $417(28)$ & $520(29.3)$ & \\
\hline
\end{tabular}

Row percentages are included

* Statistically significant at $5 \%$ level of significance

${ }^{\text {a }}$ others include, safflower oil, gingerly and rice bran oil

significant difference between women with and without GDM, in most of the food types (Table 2). Fruits and vegetable consumption ( $>6$ servings) was higher in women with normal glucose levels compared to women with GDM $(6.8 \% \mathrm{v} / \mathrm{s} 4.1 \%)$. We found that red meat ( $p$ value $=0.02)$ intake was significantly associated with GDM.

Table 3 provides the results of unadjusted and adjusted estimates in relation to GDM. The results reveal that eating red meat more than thrice a week is statistically significant $\quad(\mathrm{aRR}=2.1 ; \quad(95 \% \quad \mathrm{CI}: \quad 1.5,2.9)$ even after adjusting for other factors namely age, family history of diabetes mellitus, socioeconomic class, body mass index (BMI), the sum of skinfold thickness, metabolic equivalent of task (MET) and gestational age.

\section{Discussion}

To our knowledge, this is the first prospective study to assess the association between food habits during pregnancy and the risk of GDM among women attending public hospitals in India. In the absence of data from India, we, for the first time, show evidence that the use of red meat is significantly associated with GDM, similar to studies in different parts of the world [29, 37-39].

The meat consumption in India is on the rise, albeit much lower compared to other Western countries. We report in this study that red meat consumption and gestational diabetes are associated with relatively younger, mostly nulliparous women in the MAASTHI cohort, who are from the lower socioeconomic strata. Although red meat has emerged as a risk factor for colorectal cancer [40] and lung cancer [41] there are no studies in

Table 3 Poisson regression model of effect of dietary habits on GDM status of pregnant women adjusted for confounders ( $N=$ 1777)

\begin{tabular}{|c|c|c|c|c|c|}
\hline Variable & Categories & $\begin{array}{l}\text { Unadjusted } \\
\text { RR }(95 \% \mathrm{Cl})\end{array}$ & $P$-value & $\begin{array}{l}\text { Adjusted } \\
\text { RR }(95 \% \mathrm{Cl})\end{array}$ & $P$-value \\
\hline \multirow[t]{5}{*}{ Red Meat consumption } & Never & 1 & & 1 & \\
\hline & $<1$ per month & $1.0(0.4,2.3)$ & 0.98 & $1.2(0.6,2.4)$ & 0.85 \\
\hline & 1 or 3 times /month & $0.8(0.49,1.2)$ & 0.26 & $0.9(0.6,1.3)$ & 0.41 \\
\hline & 1-3 times/week & $1.3(0.95,1.6)$ & 0.11 & $1.3(0.98,1.6)$ & 0.10 \\
\hline & $>3$ times /week & $2.6(1.8,3.8)$ & $<0.001^{*}$ & $2.1(1.5,2.9)$ & $<0.001^{*}$ \\
\hline
\end{tabular}

Adjusted for age, family history of diabetes mellitus, socioeconomic class, BMI (body mass index), sum of skin fold thickness, MET (metabolic equivalent of task) and gestational age

1: reference category, $\mathrm{Cl}$ Confidence Interval

* Statistically significant at $5 \%$ level of significance 
India to show the association between GDM and red meat consumption. Several causal mechanisms can explain GDM and red meat consumption. First, studies have shown that heme iron in red meat may be causing GDM [42], excess iron has been implicated in increasing the insulin resistance and the risk of type 2 diabetes. It is important to consider here that all public hospitals in India supplement pregnant women with Iron tablets irrespective of their iron status. Increased iron supplements in pregnant women without iron deficiency were related to an increased risk of GDM [43]. Thus, high red meat consumption and indiscriminate iron supplementation may be related to GDM. Qiet al earlier reported a higher consumption of red meat to increased risk of coronary heart disease among women with type 2 diabetes. Secondly, red meat is also high in saturated fat and cholesterol, thus affecting insulin sensitivity and beta-cell function $[44,45]$. We found that there is inadequate consumption of vegetables and fruits in pregnant women attending public hospitals; women in lower socioeconomic strata often have limited access to nutritious food; their dietary choices are determined by affordable food items, social rank within the household and intrahousehold food allocation [46, 47]. According to national family health survey, more than half $(50.4 \%)$ of pregnant women are anemic in India [48] and the recent comprehensive national nutrition survey revealed $30.9 \%$ of adolescents are vitamin B12 deficient [49]. On the other hand, rapid urbanization has resulted in nutrition transition, and it is estimated that 166 million adults are overweight and obese, and 73 million are diabetic [9]. Thus, India is at a unique juncture where both undernutrition and overweight has to be addressed by the public health system as non-communicable diseases are no longer the disease of the upper strata.

Among the strengths, this research was done in a fairly large sample with due considerations of confounding factors. Our data provide an independent risk factor for gestational diabetes that suggests that high red meat consumption thereof was associated with an increased risk of having GDM. These findings may be useful in dietary counselling during pregnancy. The limitations of the study are that we have not assessed portion size, and second, the questionnaires were not validated, and responses were recorded based on the participants' recall. Third, we have not been able to adjust for dietary energy intake, we agree that it is a major limitation given that it might confound the overall association. Fourth, although we have identified associations between GDM incidence and red meat consumption, we do not suggest any causation and future studies are required to investigate this further.

\section{Conclusion}

The results reported in this study indicated that a high intake of red meat is associated with an increased risk of having GDM. A further detailed evaluation of the diet, analyzing quality and quantity, is needed to understand the risk profile in this population better. Diet counselling for pregnant women at public hospitals can focus on preventing adverse pregnancy outcomes. Interventions to educate women in lower socioeconomic strata on inexpensive, seasonal, and healthy food might be helpful.

\section{Supplementary information}

Supplementary information accompanies this paper at https://doi.org/10 1186/s40795-020-00388-x.

Additional file 1. Questionnaire. The file has the food habit

questionnaire used in the study.

\section{Abbreviations}

BMI: Body mass index; GDM: Gestational diabetes mellitus; MET: Metabolic equivalent of task; T2DM: Type 2 diabetes mellitus

\section{Acknowledgements}

We sincerely thank the Department of Health and Family Welfare, Government of Karnataka (DoHFW, GoK), and The Bruhat Bengaluru Mahanagara Palike (BBMP) for permitting us to conduct the study and providing constant support. We thank hospitals under DoHFW, GoK, Superintendents, Medical Officers, doctors, and all the support staff of the department for assistance in an ongoing study. We thank Ms. Eunice Lobo, Ms. Srinidhi Koya, and Ms. Daisy John for the critical review of the manuscript. Thanks to Ms. Yamuna for helping with the MET value calculations. Thanks to Dr. Anjaly Krishnan for support with the analysis. Sincere thanks to Dr. Suresh Shapeti and Mr. T.S. Ramesh for the administrative support. We thank all the team members of MAASTHI for their support in carrying out research activities in the field. We thank all participants for their participation in the ongoing cohort.

\section{Authors' contributions}

DR was involved in conceptualization, investigation, formal analysis and writing- original draft preparation. MGL was involved in formal analysis, reviewing and editing. OVS did critical review and editing of the manuscript. GRB supervised the study, designed the methodology, edited and reviewed the manuscript for submission. All authors have read and approved the manuscript.

\section{Funding}

This work was supported by the Wellcome Trust DBT India Alliance Fellowship (grant number: IA/CPHI/14/1/501499) to Giridhara R Babu. The funding agency had no role in the design and conduct of the study; collection, management, analysis, and interpretation of the data; preparation, review, or approval of the manuscript; or decision to submit the manuscript for publication.

\section{Availability of data and materials}

The datasets used and analysed during the current study are available from the corresponding author on reasonable request.

\section{Ethics approval and consent to participate}

The study was reviewed and approved by the institutional ethical review board at the Bangalore campus of IIPH-H (Ref No: IIPHHB/TRCIEC/091/2015 Dated 13/11/2015). Written informed consent was obtained from all the enrolled participants of the study for participation in the study and presentation of anonymized results through publications in journals and reports. 


\section{Competing interests}

The authors declare that they have no competing interests.

\begin{abstract}
Author details
'Indian Institute of Public Health-Bangalore, Public Health Foundation of India (PHFI), Bangalore, India. Indian Institute of Public Health-Hyderabad, Public Health Foundation of India (PHFI), Hyderabad, India. ${ }^{3}$ Care and Public Health Research Institute, Maastricht University, Maastricht, Limburg, The Netherlands. ${ }^{4}$ Lifecourse epidemiology, Indian Institute of Public Health-Bangalore, Public Health Foundation of India (PHFI), Magadi Road I cross, SIHFW premises, Bengaluru 560023, India. ${ }^{5}$ Public health and clinical medicine, Wellcome Trust/DBT India Alliance, New Delhi, India.
\end{abstract}

Received: 24 May 2020 Accepted: 12 October 2020

Published online: 19 November 2020

\section{References}

1. WHO. In: WHO/NCD/NCS/992, editor. Definition, diagnosis and classification of diabetes mellitus and its complications. Part 1: diagnosis and classification of diabetes mellitus. Geneva: World Health Organization; 1999.

2. Catalano PM, McIntyre HD, Cruickshank JK, McCance DR, Dyer AR, Metzger $\mathrm{BE}$, et al. The hyperglycemia and adverse pregnancy outcome study: associations of GDM and obesity with pregnancy outcomes. Diabetes Care. 2012;35(4):780-6.

3. Kalra P, Kachhwaha CP, Singh HV. Prevalence of gestational diabetes mellitus and its outcome in western Rajasthan. Indian J Endocrinol Metab. 2013;17(4):677

4. Saxena P, Tyagi S, Prakash A, Nigam A, Trivedi SS. Pregnancy outcome of women with gestational diabetes in a tertiary level hospital of North India. Indian J Community Med. 2011;36(2):120.

5. van Hoorn J, Dekker G, Jeffries B. Gestational diabetes versus obesity as risk factors for pregnancy-induced hypertensive disorders and fetal macrosomia. Aust N Z J Obstet Gynaecol. 2002:42(1):35-40.

6. Coustan DR. Gestational diabetes mellitus. Clin Chem. 2013;59(9):1310-21.

7. Kim C, Newton KM, Knopp RH. Gestational diabetes and the incidence of type 2 diabetes: a systematic review. Diabetes Care. 2002;25(10):1862-8.

8. Bellamy L, Casas J-P, Hingorani AD, Williams D. Type 2 diabetes mellitus after gestational diabetes: a systematic review and meta-analysis. Lancet. 2009;373(9677):1773-9.

9. Cho N, Shaw J, Karuranga S, Huang Y, da Rocha FJ, Ohlrogge A, et al. IDF diabetes atlas: global estimates of diabetes prevalence for 2017 and projections for 2045. Diabetes Res Clin Pract. 2018;138:271-81.

10. Li KT, Naik S, Alexander M, et al. Screening and diagnosis of gestational diabetes in India: a systematic review and meta-analysis. Acta Diabetol. 2018:55:613-25. https://doi.org/10.1007/s00592-018-1131-1.

11. Basu J, Datta C, Chowdhury S, Mandal D, Mondal NK, Ghosh A. Gestational diabetes mellitus in a tertiary care hospital of Kolkata, India: prevalence, pathogenesis and potential disease biomarkers. experimental and clinical endocrinology \& diabetes; 2018.

12. Seshiah V, Cynthia A, Balaji V, Balaji MS, Ashalata S, Sheela R, et al. Detection and care of women with gestational diabetes mellitus from early weeks of pregnancy results in birth weight of newborn babies appropriate for gestational age. Diabetes Res Clin Pract. 2008;80(2):199-202.

13. Bashir M, Baagar K, Naem E, Elkhatib F, Alshaybani N, Konje JC, et al. Pregnancy outcomes of early detected gestational diabetes: a retrospective comparison cohort study. Qatar BMJ Open. 2019;9(2):e023612.

14. Nielsen KK, Damm P, Kapur A, Balaji V, Balaji MS, Seshiah V, et al. Risk factors for hyperglycaemia in pregnancy in Tamil Nadu, India. PloS one. 2016;11(3): e0151311.

15. Zhu Y, Hedderson MM, Quesenberry CP, Feng J, Ferrara A. Central obesity increases the risk of gestational diabetes partially through increasing insulin resistance. Obesity. 2019;27(1):152-60.

16. Chu SY, Callaghan WM, Kim SY, Schmid CH, Lau J, England LJ, et al. Maternal obesity and risk of gestational diabetes mellitus. Diabetes Care. 2007:30(8):2070-6

17. Babu GR, Deepa R, Glenda M, Katon JG, Daniel A. Do gestational obesity and gestational diabetes have an independent effect on neonatal adiposity? Results of mediation analysis from a cohort study in South India. Clin Epidemiol. 2019;11:1067-80.

18. Jensen DM, Damm P, Sørensen B, Mølsted-Pedersen L, Westergaard JG, Klebe J, et al. Clinical impact of mild carbohydrate intolerance in pregnancy: a study of 2904 nondiabetic Danish women with risk factors for gestational diabetes mellitus. Am J Obstet Gynecol. 2001;185(2):413-9.

19. Banerji MA, Faridi N, Atluri R, Chaiken RL, Lebovitz HE. Body composition, visceral fat, leptin, and insulin resistance in Asian Indian Men. J Clin Endocrinol Metab. 1999;84(1):137-44.

20. Barker DJ. The developmental origins of chronic adult disease. Acta Paediatr. 2004;93:26-33.

21. Fall C. Nutrition in fetal life and childhood and its linkage with adult noncommunicable disease: lessons from birth cohort studies in India. Proc Indian Natl Sci Acad. 2018;84(4):881-9.

22. Bo S, Menato G, Lezo A, Signorile A, Bardelli C, De Michieli F, et al. Dietary fat and gestational hyperglycaemia. Diabetologia. 2001;44(8):972-8.

23. Morisset AS, St-Yves A, Veillette J, Weisnagel SJ, Tchernof A, Robitaille J. Prevention of gestational diabetes mellitus: a review of studies on weight management. Diabetes Metab Res Rev. 2010;26(1):17-25.

24. Lotfi MH, Fallahzadeh $H$, Rahmanian M, Hosseinzadeh M, Lashkardoost $H$, Doaei S, Gholamalizadeh M, Hamedi A. Association of food groups intake and physical activity with gestational diabetes mellitus in Iranian women. J Matern Fetal Neonatal Med. 2020;33(21):3559-64.

25. Bao W, Tobias DK, Olsen SF, Zhang C. Pre-pregnancy fried food consumption and the risk of gestational diabetes mellitus: a prospective cohort study. Diabetologia. 2014;57(12):2485-91.

26. Dominguez $\sqcup$, Martínez-González MA, Basterra-Gortari FJ, Gea A, Barbagallo M, Bes-Rastrollo M. Fast food consumption and gestational diabetes incidence in the SUN project. PLoS One. 2014;9(9):e106627.

27. Bao W, Tobias DK, Hu FB, Chavarro JE, Zhang C. Pre-pregnancy potato consumption and risk of gestational diabetes mellitus: prospective cohort study. bmj. 2016;352:h6898.

28. Zhang C, Schulze MB, Solomon CG, Hu FB. A prospective study of dietary patterns, meat intake and the risk of gestational diabetes mellitus. Diabetologia. 2006;49(11):2604-13.

29. Schoenaker DAJM, Mishra GD, Callaway LK, Soedamah-Muthu SS. The role of energy, nutrients, foods, and dietary patterns in the development of gestational diabetes mellitus: a systematic review of observational studies. Diabetes Care. 2016;39(1):16-23.

30. Carolan M, Gill GK, Steele C. Women's experiences of factors that facilitate or inhibit gestational diabetes self-management. BMC Pregnancy Childbirth. 2012:12(1):99.

31. Babu GR, Murthy G, Deepa R, Kumar HK, Karthik M, Deshpande K, et al. Maternal antecedents of adiposity and studying the transgenerational role of hyperglycemia and insulin (MAASTHI): a prospective cohort study. BMC Pregnancy Childbirth. 2016;16(1):311.

32. Bharathi AV, Kuriyan R, Kurpad AV, Thomas T, Ebrahim S, Kinra S, et al. Assessment of physical activity using accelerometry, an activity diary, the heart rate method and the Indian migration study questionnaire in south Indian adults. Public Health Nutr. 2010;13(1):47-53.

33. Kumar BR, Dudala SR, Rao A. Kuppuswamy's socio-economic status scale-a revision of economic parameter for 2012. Int J Res Dev Health. 2013;1(1):2-4

34. Metzger B, Gabbe S, Persson B, Buchanan T, Catalano P, Damm P, et al. International Association of Diabetes and Pregnancy Study Groups Consensus Panel. International association of diabetes and pregnancy study groups recommendations on the diagnosis and classification of hyperglycemia in pregnancy. Diabetes Care. 2010;33(3):676-82.

35. IBM Corp. Released 2015. IBM SPSS Statistics for Windows, Version 23.0. Armonk: IBM Corp.

36. R Core Team. R: a language and environment for statistical computing. $\mathrm{R}$ Foundation for Statistical Computing, Version 3.6.2, Vienna; 2020. https:// www.R-project.org/.

37. Marí-Sanchis A, Díaz-Jurado G, Basterra-Gortari FJ, de la Fuente-Arrillaga C, Martínez-González MA, Bes-Rastrollo M. Association between pre-pregnancy consumption of meat, iron intake, and the risk of gestational diabetes: the SUN project. Eur J Nutr. 2018;57(3):939-49.

38. Bao W, Bowers K, Tobias DK, Hu FB, Zhang C. Prepregnancy dietary protein intake, major dietary protein sources, and the risk of gestational diabetes mellitus: a prospective cohort study. Diabetes Care. 2013;36(7):2001-8.

39. Zareei S, Homayounfar R, Mehdi Naghizadeh M, Ehrampoush E, Rahimi M. Dietary pattern in pregnancy and risk of gestational diabetes mellitus (GDM). Diabetes Metab Syndr. 2018;12(3):399-404.

40. Malhotra S. Geographical distribution of gastrointestinal cancers in India with special reference to causation. Gut. 1967:8(4):361. 
41. Ganesh B, Sushama S, Monika S, Suvarna P. A case-control study of risk factors for lung cancer in Mumbai, India. Asian Pac J Cancer Prev. 2011; 12(2):357-62.

42. Darling A, Mitchell A, Werler M. Preconceptional iron intake and gestational diabetes mellitus. Int J Environ Res Public Health. 2016;13(6):525.

43. Helin A, Kinnunen TI, Raitanen J, Ahonen S, Virtanen SM, Luoto R. Iron intake, haemoglobin and risk of gestational diabetes: a prospective cohort study. BMJ Open. 2012;2(5):e001730

44. Longvah T, Ananthan R, Bhaskarachary K, Venkaiah K. Indian food composition table. Telangana: National Institute of Nutrition; 2017.

45. Lovejoy JC, Champagne CM, Smith SR, DeLany JP, Bray GA, Lefevre M, et al. Relationship of dietary fat and serum cholesterol ester and phospholipid fatty acids to markers of insulin resistance in men and women with a range of glucose tolerance. Metab-Clin Exp. 2001;50(1):86-92.

46. Messer E. Intra-household allocation of food and health care: current findings and understandings-introduction, Social Science \& Medicine. Great Britain: Elsevier; 1997. pp. 1675-84.https://doi.org/10.1016/S02779536(96)00370-X.

47. Harris-Fry H, Shrestha N, Costello A, Saville NM. Determinants of intrahousehold food allocation between adults in South Asia - a systematic review. Int J Equity Health. 2017;16(1):107.

48. National Family Health Survey, India-4 [Internet]. Ministry of Health and Family Welfare. 2015-16. Available from: http://rchiips.org/NFHS/nfhs4.shtml. [cited 19/7/2017].

49. Ministry of Health and Family Welfare (MoHFW) Gol. Comprehensive National Nutrition Survey (CNNS) National Report, vol. 2019. New Delhi: UNICEF and Population Council; 2019.

\section{Publisher's Note}

Springer Nature remains neutral with regard to jurisdictional claims in published maps and institutional affiliations.

Ready to submit your research? Choose BMC and benefit from:

- fast, convenient online submission

- thorough peer review by experienced researchers in your field

- rapid publication on acceptance

- support for research data, including large and complex data types

- gold Open Access which fosters wider collaboration and increased citations

- maximum visibility for your research: over $100 \mathrm{M}$ website views per year

At $\mathrm{BMC}$, research is always in progress.

Learn more biomedcentral.com/submissions 